Flights of wild geese and wild duck, the former coming from the great Hungarian marshes, are frequent sights at the time of hunter's moon. Insect life includes a wealth of butterflies and the curious Yugoslav tiger moth, Cymbaciophora pudica, which produces a loud squeaking or clattering noise by its wings in flight. The caves of Dalmatia and Carinthia have long interested naturalists for their blind olm or cave newt, Proteus anguineus. The flora is rich in alpine flowers of great beauty. Pančic wrote a useful "Flora of Serbia", and recently Hayek compiled a new Balkan flora. It is an irony that one of its most recent students was Dr. Giuseppi, the Italian botanist and member of the Alpine Club. On his 1930 visit he found Geranium subcaulescens on Mount Koprevnia and Saxifraga montegrina, receiving the award of merit of the Royal Horticultural Society when introducing the former to British gardens. On Mount Cristen he found Ranunculus creatus, and in 1931 on Kerast he found $R$. Wettsteisii and Ardrosance Hedreantha, on Ljuetia, Viola Grisebachiana. W. B. Turrill, of Kew, also studied the Balkan flora during the War of 1914-18 and three times since. Good herbaria existed at Belgrade, Sofia and Trieste. Tournefort, Sibthorp, Clark, D'Urville and Grisebach collected in the area, which has a flora of some 6,500 species.

\section{International Relations and Federalism}

The February 1941 issue of Union, the monthly forum of the New Commonwealth Society, includes a number of articles on post-war reconstruction and the development of international relations. Mr. Duncan Hall, in an address on "What are the hopes of Lasting Peace?" asserts that only by a scientific understanding of the dynamic forces of human nature and human society, by a realistic education and a wise leadership, can we hope to speed up man's progress towards a lasting peace, based on the supremacy of reason and conscience. The problem is far more than one of finding the right institutions and making economic adjustments. It is essentially a problem of how to control the human forces, how to prevent uneven domestication, how to safeguard against mob situations that break down the conscience and reason of the individual and let loose his instinctive forces. Writing on "The Outline of a Long-Term Economic Plan", Mr. W. L. Fairweather urges that the task ahead of us is to raise the level of consumption all over the world, and that many of the controls necessary in war will be extended and developed and remain as a permanent feature of the economic system. Mr. Channing-Pearce's address to the Oxford Branch of Federal Union on January 4 on "The Federal Faith" is included, with its conception of federation as concerned not only with politics but also with sociology and economics.

\section{The Wilkes Centenary}

THE centenary of the Wilkes Exploring Expedition of the United States Navy, 1838-1842, was marked by a symposium on American polar exploration organized by the American Philosophical Society in
February of last year. The papers read on that occasion are now published (Proc. American Phil. Soc., 82, No. 5) and include some valuable contributions to polar geography. The expedition is best remembered for its antarctic landfalls, which have since been the subject of much controversy but mainly have bien confirmed. The expedition had, however, a pracical bias, actuated by the considerable American whaling industry in the Pacific at that time, and the scientific side was not too strong though valuable results were obtained not only in the antarctic but also in many surveys in Pacific islands and numerous biological collections. The greater part of the results were published by the authority of Congress, but the edition was small and many of the volumes are rare. In the present publication the history of the expedition and the story of the struggle to get the reports published are fully traced and there are valuable bibliographical records.

A most useful paper deals fully with the fishes collected by the expedition, a report which has not previously appeared. This is by Mr. H. W. Fowler. Another paper, by Commander F. W. Reichelder, discusses the contributions of the expedition to magnetism, gravity and meteorology. Prof. W. M. Hobbs treats of the geographical discoveries. Another series of papers deals with other aspects of American polar work. Of these may be noted one by Mr. W. E. Ekblaw on the aretic discoveries of De Haven, Kane and Hall and another by Mr. H. J. Lee on Peary's journeys in North.Greenland. Two valuable and original papers are those by Prof. L. M. Could on the glaciers of Antarctica, which surveys all the glaciological problems, and one by Mr. V. Stefansson in which, with his customary bold conception, he advocates a ten-year programme of arctic studies to be centred in a number of stations, most of them on the pack-ice, to be established and maintained by air.

\section{Early Man in Virginia}

For some little time evidence has been accumulating which points to Bedford County, in southwestern Virginia, as a place of early settlement of stone-using aboriginal tribes of nomadic hunters. During proto-historic and early historic times, Siouian and Iroquoian tribes appear to have lived within the present bounds of the county; while the Cherokee in the earlier half of the nineteenth century still retained the memory of an old tradition that a Cherokee village once stood near the twin Peaks of Otter in the north-west of the county where it is crossed by the Blue Ridge. These peaks were formerly thought to be possibly among the highest of the northern continent; and it is believed that the region around had been occupied for many centuries by a succession of tribes of different stocks, ever since the time when nomadic bands first entered the wilderness. This belief has now received the support of recent discovery in the form of stone implements of an early type on a site, now known as the Mons site, which was revealed early in 1940 in road-making operations in the vicinity of the Peaks of Otter. In a description of the site and finds by David $\mathrm{I}$. 